\title{
LANGUAGE POWER IN THE CLASSROOM VIEWED FROM NIETZSCHE AND HEIDEGGER
}

\author{
Moh. Yamin ${ }^{1,2, *}$, Fabiola Dharmawanti Kurnia ${ }^{3}$, Ali Mustofa ${ }^{4}$ \\ ${ }^{1}$ English Education Department, Faculty of Teacher Training and Education, Universitas Lambung \\ Mangkurat, Jl. Brigjen H. Hasan Basry Kayu Tangi Banjarmasin 219, Indonesia \\ ${ }^{2}$ Art and Language Education Department, Doctoral Program, Universitas Negeri Surabaya, Jl. Lidah Wetan \\ Surabaya 60213, Indonesia \\ ${ }^{3}$ Art and Language Education Department, Doctoral Program, Universitas Negeri Surabaya, Jl. Lidah Wetan \\ Surabaya 60213, Indonesia \\ ${ }^{4}$ Art and Language Education Department, Doctoral Program, Universitas Negeri Surabaya, Jl. Lidah Wetan \\ Surabaya 60213, Indonesia
}

\section{ARTICLE INFO}

Keywords:

Heidegger

Language

Language Power

Nietzsche

Article History:

Received: 27/10/2019

Accepted: 31/05/2020

Available Online:

31/05/2020

\begin{abstract}
Language should be viewed as the space to build the interaction. The classroom practice in which the teacher and students interact in a teachinglearning activity should be empowered through language. To produce a language aura that can be paid attention by the participants, it is important to put language as the power in the positive side in which every participant respect the language as the power to tie each other. This study aims to explore Nietzsche's and Heidegger's views on the use of language and language power in the classroom and to compare both of their views in the classroom. The expected study is that it has the significance of using the language as the center of communication and teaching-learning. The descriptive qualitative method is applied. The data are taken from four research articles on Nietzsche's and Heidegger's views dealing with language power in the classroom. Findings and results from each research article are the data for this study. Every finding and result of the research article becomes the data source to discuss. The findings show that the capability in using language can be the space of power so that it drives the class to become effective and there is an interactive dialogue between the teacher and students.
\end{abstract}

2442-305X / (C) 2020 The Authors, this is open access article under the (CC-BY-NC) license (https://creativecommons.org/licenses/by-nc/4.0/), DOI: 10.19105/ojbs.v14i1.2683

\footnotetext{
$\overline{* \text { Corresponding Author: }}$

Email address: moh_yamin@ulm.ac.id (Moh. Yamin)
}

\section{A. Introduction}

The capability in expression is needed to be able to be the ones responding to the fact and realities. Expressing capability means that anyone should be able to communicate well so that they are the main part of the dialogue. The ability to communicate is expressed by language. Language is the medium for people to deliver their minds, their 
thinking, their ideas, and thought to others. Language as the medium of communication should be viewed as the corpus that should be guided and improved so that it has valuable value for communication.

Nietzsche states that language should appear to construct the world. ${ }^{1}$ The world created by the language is the space in which we or anybody can express thought and mind. The world should be defined as the space to share the ideas, therefore, the world's existence created by the language has the meaning. The meaning is for us or anybody staying or living in the space. Classroom as the space of interaction between the teacher and students can be meant as the world in which the classroom will be substantial when there are value and meaning there.

Bingham in analyzing Nietzsche's view dealing with language says that language "lives" first and foremost as an assertion of power relations. This implies that the power of language in the classroom is determined by the one who speaks and pays attention. The speaker can be the teacher or students, and the listener can be the teacher or students too. Principally, as long as the position of language is meant to create the dialogue inter-rationally between the teacher and students, a good atmosphere in the classroom will be created.

Because of that, language is "alive" and it exceeds the voices of both the

\footnotetext{
1 Tracy B. Strong, "Language and Nihilism: Nietzsche's Critique of Epistemology," Theory and Society 3, no. 2 (1976): 239-63, https://www.jstor.org/stable/656848.
}

teacher and students. Living language embodies the sedimented history of those who have been in a position to name and those who have not. Language in the classroom context is viewed as the tool of communicating. $^{2}$ In understanding language power in the classroom, it is important to understand language as a communication tool in which a piece of linguistic structure can represent various meanings, depending on the context. Language is the main substance of symbolic activity carried out by humans and it is a complex substance. ${ }^{3}$

Nietzsche writes that language is "symbolizing which becomes clearer and clearer" what becomes clearer, more differentiated is the symbol itself, the conscious representation in language. In language, the word is a symbol of a symbol. Conscious language ultimately symbolizes a further differentiation, an ever clearer symbolization meaning a weakened or inadequate expression of the original symbol. ${ }^{4}$ What Nietzsche means, language is the space in which the people reflect their imagination and thought in spoken and written form. Language is the field in which the people articulate their understanding and

\footnotetext{
2 Charles Bingham, "The Goals of Language, The Language of Goals: Nietzsche's Concern with Rethoric and Its Educational Implications," Educational Theory 48, no. 2 (1998): 229-40.

3 Pateda in Susi Harliani, "The World of Translation," OKARA: Jurnal Bahasa dan Sastra 13, no. 1 (2019): 121 , https://doi.org/10.19105/ojbs.v13i1.2272.

${ }^{4}$ Ernst Behler et al., The Beginnings of Nietzsche's Theory of Language, New York (Berlin: de Gruyter, 1988).
} 
interpretation in symbols containing meanings and messages.

It is important to state that language should be meant to communicate any messages through symbols. Through symbols, some meanings and messages should be delivered. Nietzsche in this context positions language as the struggle to deliver messages. Language is the place in which every person as speaker and listeners can deliver what to deliver.

It is in line with what Heidegger said, language is held to be a kind of communication. It serves for verbal exchange and agreement, and in general for communicating. Language is not only and not primarily an audible and written expression of what is to be communicated, but also puts forth in words and statements that are overtly or covertly intended to be communicated.

Language alone brings what is into the open for the first time. Where there is no language, there is also no openness of what is, and consequently no openness either of that which is not and of the empty. ${ }^{5}$ In Heidegger's perspective, language has the role to communicate what is not communicated yet and to deliver what to deliver to be clear and understandable concerning the messages. Language is the center of communication, tries to simplify the difficult and abstract concept into an easy and simple concept. That is the goal of language use.

In classroom use, Heidegger offers the language concept in which language

5 Martin Heidegger, Poetry, Language, Thought (New York: HarperCollins Publishers., 2001), https://doi.org/10.2307/40126613. mediates communication problems because of the difficult concept to read and to understand.

Heidegger then adds his view, language is only there, where it is spoken, where it happens, that is, human beings. The language would be spoken according to all of its directions and possibilities. ${ }^{6}$ Overall, language is the expression of how it reflects the mind, thought, and ideas. Therefore, language exists because human beings use it for communicating and for uttering the messages to deliver. Language is the identity of how human beings promote themselves in interaction and conversation. In each interaction and conversation, there will be efforts to make ideas and thought delivered to others; this condition explains the role of language as the tool of communicating and speaking.

Language is meaningful and has a contribution because it is used to discuss and communicate. Language has the meaning because it attends to mean and interpret what human beings do and speak. Language is not the one missing from human beings' activities and language is not the human beings' apparatus that should be away and avoided. It is important to state that language is inherent in every human beings' activity wherever and whenever. Therefore, language is the one that explains human beings' lives, and their lives should be arranged in a meaningful one so that it can speak for.

\footnotetext{
6 Martin Heidegger, Logic as the Question Cencerning the Essence of Language (New York: State University of New York Press, 2009).
} 
Heidegger's idea of dealing with language as Zwiesprache among worldly participants is interesting to study furtherly. The language provides the vocabulary to express the ineluctable drama of existence, the subtleties, twists of phrase, and nuances to articulate the meaning of care as finite. ${ }^{7}$ It opens the space for every person to debate and the debate will create the conflict in which the conflict itself is the expression that language happens there. Language is the space of self contest to be able to speak freely.

What should be emphasized in Heidegger's idea dealing with language is that it is the tool in speaking and explaining in all contexts. The classroom as the place in which the students learn is the center for all learners and the teacher to be able to make a dialogue. The language power in dialogue happens when there is a conflict that is created because the conflict itself is the trigger in producing interactive dialogue. Conflict in dialogue is meant to create any topics to discuss contributing to the existence of language power needed to activate the interaction and participation among the participants. Conflict in language for the dialogue interest is aimed to attend the participation giving contribution towards the use of language as the tool of dialogue. "Language is power" in this context is meant to explain the language position to share the knowledge and

\footnotetext{
${ }^{7}$ Frank Schalow, "Language and the Social Roots of Conscience: Heidegger's Less Traveled Path," Human Studies 21, no. 2 (1998): 141-56, https://doi.org/10.1023/A:1005312105548.
}

understanding dealing with the knowledge.

The study of $\mathrm{YU}$ dealing with pedagogy of Heideggerian (Un)Truth opens the perspective on explorations of(un)truth in clearings between brightness and darkness in which the openness is needed. Teaching in the classroom is not only dealt with what to deliver but also to comprehend each other. Furtherly, the classroom should be interpreted as the open space in which the open-minded is required. ${ }^{8}$ A similar study on Heideggerian studies conducted by d'Agnese built a conception of selfhood and subjectivity in terms of freedom, responsibility, and ongoing transformation in which classroom is the part to teach the freedom to think and to speak. ${ }^{9}$

Nietzschean perspective in viewing classroom as the space of dialogue is based on logic in which logic is connected with learning, and this is connected with habituation through which the students internalize patterns of behavior. Nietzsche connects learning and habituation with experience. The person acquires experience from everyday life and through the senses from the external world. In a word, logic, learning, and experience are the sources for the learner to learn. Therefore, the teacher's attendance in the

8 Jie Yu, "The Pedagogy of Heideggerian (Un)Truth: How Can We See Stars by Day in a Deep Dark Well?," Journal of Curriculum and Pedagogy 11, no. 1 (2014): 50-63, https://doi.org/10.1080/15505170.2014.893215.

9 Vasco D'Agnese, “'Not-Being-at-Home': Subject, Freedom and Transcending in Heideggerian Educational Philosophy," Studies in Philosophy and Education 37, no. 3 (2018): 287-300, https://doi.org/10.1007/s11217-018-9598-3. 
classroom is to shape and activate all these elements. ${ }^{10}$ In Yacek's study about Nietzsche, he viewed the classroom as multicultural dialogue and we need to promote mutual understanding in dialogue. ${ }^{11}$

From the discussions, it seems that the specific discussion on the formulation of language power in the classroom used, it is not stated in detail and rigidly. Therefore, it is very interesting to discuss the two thinkers concerning language. The two thinkers here are Nietzsche and Heidegger. This study aims to explore their thinkings and views dealing with language as the language power in the classroom. The expected significance is that it has a significant contribution towards language understanding as to the teaching-learning communicating way in varieties of goals. From the result of exploration, the researcher intends to map the language power in the classroom as the teaching-learning activity among the teacher and students.

\section{B. Method}

This research is a descriptive method with a qualitative approach. The source of data dealing with Nietzsche and Heidegger in language philosophy is taken from relevant books and several journal articles. Because the academic

\footnotetext{
${ }^{10} \mathrm{Yu}$, "The Pedagogy of Heideggerian (Un)Truth: How Can We See Stars by Day in a Deep Dark Well?"

11 Douglas W. Yacek, "Learning to See with Different Eyes: A Nietzschean Challenge to Multicultural Dialogue," Educational Theory 64, no. 2 (2014): https://doi.org/10.1111/edth.12052.
}

sources are not limited, the findings and discussion will be in detail. To make clear the indicators of the data dealing with language philosophy, it is important to state clearly in the following traits:

1. Language is viewed as a way of communication;

2. Language is viewed as the way of delivering the messages;

3. Language is power in communicating and delivering the messages;

4. Language is the tool to share and to discuss.

All 4 traits are recorded and reflected in each table of Nietzsche's and Heidegger's thought appearing in the result. Based on the four points dealing with the language philosophy used in interaction and conversation that happens in the classroom, the analysis in viewing Nietzsche's and Heidegger's thought should be correlated in the classroom use in which how the language has the role in mediating the teacher's task to students and students' response to the teacher.

Because the data were taken from books and relevant articles talking about Nietzsche's and Heidegger's thought, all should be displayed and analyzed descriptively and qualitatively. The descriptive performance is seen from how the data are narrated easily, clearly, and concisely to make them meaningful. The qualitative performance is measured from how the data have significance towards the goal of the research. Therefore, the descriptive method and qualitative approach are the research framework to make the findings in the discussion have valuable meaning contributing to the goal 
of the research. The analysis technique applied is a content analysis based on the provided data. Content analysis is meant that how all data can give meanings and messages towards language power interest in the classroom. As a result, the role of language power contributes towards the goal of teaching and learning activity; the teacher and students position language power not to dominate each other, but to make proportionate the teachers' task and students' task in the classroom proportionally.

\section{Results}

1. Language Power based on Nietzsche's View

There are basic thoughts about language power emphasized by Nietzsche illustrated in table 1 below.

Table 1.

Main Ideas of Nietzsche in Language Philosophy

\begin{tabular}{ll}
\hline No & Elaboration \\
\hline 1. & $\begin{array}{l}\text { The deepest philosophical knowledge } \\
\text { lies already prepared in language and } \\
\text { started from the perfecting of grammar }\end{array}$ \\
2. $\begin{array}{l}\text { Language is a product of instinct } \\
\text { (Instinct is purposive action without } \\
\text { consciousness of the purpose) }\end{array}$ \\
3. Every conscious thinking first possible \\
with the help of language; something \\
expedient can be without \\
consciousness. \\
Language is neither the conscious \\
work of individuals nor of a majority \\
Instincts were considered to be natural, \\
involuntary, constraining, and \\
unchangeable; language, on the other \\
hand, was seen as being spiritual, free, \\
conscious, and adaptable
\end{tabular}

Source: Crawford ${ }^{12}$ and Werner ${ }^{13}$

12 Behler et al., The Beginnings of Nietzsche's Theory of Language.
The five points above are the main ideas of Nietzsche in viewing the language as the main tool in interacting and communicating. Understanding and viewing them should be based on how good and effective in using the language for communication interest. Language should be understood as interacting and communicating. Good language happens because of grammar that aims to perfect to utter in written or spoken one. A good language that is acceptable to communicate is based on grammar.

The first view stating "the deepest philosophical knowledge lies already prepared in language and it is started from the perfecting of grammar" is interesting to discuss. What can be in detail discussion is dealing with the importance of language position in describing the knowledge, sharing it, and also elaborate it whenever and wherever. To use the language should be viewed in a different context to have a language contribution meaningful. ${ }^{14}$ When this concept is applied in the classroom in which the teacher and students interact, language role is important to use.

Having good competence in language should be had and this is what Nietzsche wants to highlight. Good competence in language should be started from the knowledge of how the language is used and the language pattern should be learned. Commonly, preparing philosophical knowledge deals

\footnotetext{
${ }^{13}$ João Constâncio and Maria João Mayer Branco, Nietzsche on Instinct and Language (Berlin: Walter de Gruyter, 2011).

${ }^{14}$ Yacek, "Learning to See with Different Eyes: A Nietzschean Challenge to Multicultural Dialogue."
} 
with grammar. It is very important to view philosophical knowledge and grammar as the two things that relate to each other. Both of them have a role in using language that is interactive and communicative in the classroom. What should be understood from this, a classroom that is powerful dan giving contribution towards building philosophical language is started from knowledge and language use. We can communicate being both verbal and nonverbal through language because of language having a role as the bridge. We can obtain and share awareness of impression to the others. ${ }^{15}$

The second view concerning language is a product of instinct in which instinct is purposive action without consciousness of the purpose should be remembered to correlate with the previous one. Consequently, anybody who talks without thinking first actually signals that the way to speak is not built based on the correct goal. Instinct is initial consciousness in which every one of us speaks starting from instinct.

Every instinct comes into consciousness; it is called superficial dan falsifying. Therefore, that determines how one speaks is viewed from the instinct. However, consciousness itself is important to make the goal of speaking be achieved. ${ }^{16}$ Speaking should be on the

15 Stanul Grozev, "Friedrich Nietzsche on the Origins of Language and Truth," Psychological Research 20, no. 1 (2017): 7-13.

16 Paul Katsafanas, "Nietzsche's Theory of Mind: Consciousness and Conceptualization," European Journal of Philosophy 13, no. 1 (2005): 1-31, https://doi.org/10.1111/j.0966-8373.2005.00220.x. goal in which whatever spoken aims to give meanings and messages. ${ }^{17}$

The presence of the teacher and students should be viewed as the subjects who speak with consciousness and do not speak a consciousness of the purpose to achieve the goal of learning. Every phase of class activities should be well planned and in detail implemented. The use of language that creates a consciousness of the purpose is important to notice. ${ }^{18}$ In Nietzsche's view, speaking or uttering should be in the soul, and finally whatever done delivers the meanings and the meanings themselves are the part of the consciousness of the purpose.

The third view with the sentence "every conscious thinking first possible with the help of language; something expedient can be without consciousness" gives an interpretation that good speaking is started with consciousness and consciousness itself in spoken form is begun from language how it is uttered. ${ }^{19}$ Because of that, the ability to communicate in any condition should be with consciousness in as much as consciousness itself drives anyone to be able to speak. Class as the place of learning to be an interactive room should

\footnotetext{
17 Joseph Lichtenberg, "Values, Consciousness, and Language," Psychoanalytic Inquiry 22, no. 5 (2002): $841-56$, https://doi.org/10.1080/07351692209349020.

18 P. Gordon, "Language and Consciousness," in Encyclopedia of Consciousness, 2009, https://doi.org/10.1016/B978-012373873-8.000438.

19 David M. Rosenthal, "Consciousness and Its Function," Neuropsychologia 46, no. 3 (2008): 82940 ,

https://doi.org/10.1016/j.neuropsychologia.2007.11. 012.
} 
be begun from language and consciousness.

The fourth view dealing with "language is neither the conscious work of individuals nor of a majority" opens insight, whatever individuals speak and deliver will have many meanings and messages when there is an interaction among them. Consciousness in language utterances comes because every one of them do interaction, say any words or sentences that correlate with the goal and topic. Therefore, speaking with consciousness to give meanings and messages should be meant in language power that has a significant contribution towards classroom activity.

The teacher's and students presence show the importance of building consciousness among them. More concretely, consciousness in language collectively contributes towards how the language is used and spoken in the classroom. Consciousness in language speaking signals, the teacher and students should have the same consciousness to pay attention to each other.

When the teacher introduces the topic, explains the material, elaborates the material, give examples dealing with the material, the students should notice. The expression of notice is dealing with how they try to follow the phases of explanation the teacher delivers. By doing this, it is called the expression of consciousness in which all of them attend the classroom to achieve the goal of language communication in the teaching and learning activity.
Good and effective communication should be based on consciousness in which all subjects in the classroom build communicative awareness. Such a thing can bridge the goal of class presence in teaching and learning activity. Consciousness in language for communicating and interacting in the classroom is the modality. Such this is the one that will create a good atmosphere in the classroom as the space of learning and teaching. Therefore, James affirms that consciousness should be internalized in language communication to run the goal of learning and teaching. ${ }^{20}$

Practically, consciousness in language communication has the main role in delivering the messages and meanings to talk between the teacher and students. It is also stated by Walsh, he states that interactional awareness in the second language classroom which is built because they use the language according to the task in which they are involved. ${ }^{21}$ The metaphorical awareness in language use is needed as the effort to position us in good interactional awareness. Ayling adds that there will be open metaphorical awareness of language while the language used is communicative. ${ }^{22}$

20 Carl James, "A Cross-Linguistic Approach to Language Awareness," Language Awareness 5, no. $\quad 3-4$ (1996): 138-48, https://doi.org/10.1080/09658416.1996.9959903.

21 Steve Walsh, "Developing Interactional Awareness in the Second Language Classroom Through Teacher Self-Evaluation," Language Awareness 12, no. 2 (2003): 124-42, https://doi.org/10.1080/09658410308667071.

22 Douglas Ayling, "Language Can Be Thought of as Metaphor. Is This an Appropriate Metaphor?," 2002. 
The last view "instincts were considered to be natural, involuntary, constraining and unchangeable; language, on the other hand, was seen as being spiritual, free, conscious, and adaptable" is interesting to discuss dealing with language use in the classroom. Every one of us tends to use instinct in any activities, including in language communication, however; it is important to state that language should be understood to train consciousness.

Consciousness in language communication is built when the classroom interaction is with language awareness. Language awareness is the bridge for building consciousness and this is the main part explaining the attendance of language soul in a classroom activity. ${ }^{23}$ The presence of emotive-pragmatic functioning of language by considering its relation to the truth of communication goals should be had because it is the key to getting the point of communication itself ${ }^{24}$ language awareness to create a good atmosphere in the classroom is a must in improving the positive interaction among the teacher and students.

The most important thing to underline is that language used in the classroom reflects the students' awareness level in which the teacher should understand their students. Therefore, Nietzsche's view in perceiving language as the tool for communicating

23 James, "A Cross-Linguistic Approach to Language Awareness."

${ }^{24}$ Roger Hazelton, "Nietzsche 's Contribution to the Theory of Language," The Philosophical Review 52, no. 1 (1943): 47-60. and interacting in the classroom tries to position language to embrace all. The acceptable language is when it is the tool for communicating among them. The language for all is the one in which every one of them can use the language for communication and communicating. ${ }^{25}$

Something interesting from Nietzsche's view is that language should appear to construct the world in which the world can be embodied as the classroom, the space that aims to educate the students done by a teacher. Constructing the world in the classroom has a meaningful message creating consciousness in teaching, explaining, giving any examples, etc done by a teacher.

It is a part of constructing the world itself in the classroom; students in other sides who can interact, pay attention, raise a question to the teacher, and give feedback is also a part of constructing the world in the classroom in consciousness for language communication. Either the teacher or the students are the subject as a language-effect in which the class as the space in language interaction should be meaningful to the intended goal. ${ }^{26}$

Language in any uses has the main role in clearing and cleaning boundaries among the subjects and the subject of the classroom is a teacher and students. Language is meant to share and transfer

${ }^{25}$ Christian J. Emden, Nietzsche on Language, Consciousness, and the Body (Illinois: University of Illinois Press, 2005).

26 Jerrold Seigel, "The Human Subject as A Language-Effect," History of European Ideas 18, no. 4 (1994): 481-95, https://doi.org/10.1016/01916599(94)90081-7. 
any variations of understanding, interpretation, and view among the teacher and students; all of them are subjects that position themselves in building collective consciousness indicating that the language used is meaningful. ${ }^{27}$

In the other words, language power in Nietzsche's view is the concept of communication aiming to build the spirit of paying attention and giving meaning towards everything the teacher and students do in the classroom as the process of educating. All must be able to think beyond the text whether for the teacher or the students. Class as the language space bridges them to be the subjects creating empowering and educating dialogue to attain the goal of learning. ${ }^{28}$

\section{Language Power based Heidegger's View}

In Heidegger's view, language power determines how someone talks and others give attention. Concerning this, Heidegger proposes six main basic principles illustrated in table 2.

\footnotetext{
${ }^{27}$ M. L. Wales, "Aspects of Language Awareness Used in Some Workplace Esl Programmes," Language Awareness 2, no. 2 (1993): 85-104, https://doi.org/10.1080/09658416.1993.9959823.

28 James R. Watson, "Nietzsche's 'Transnational' Thinking," History of European Ideas 15, no. 1-3 (1992): 133-40; Nimrod Aloni, "Empowering Dialogues in Humanistic Education," Educational Philosophy and Theory, 2011, 1-15, https://doi.org/10.1111/j.1469-5812.2011.00789.x.
}

Table 2.

Main Ideas of Heidegger in Language Philosophy

\begin{tabular}{ll} 
No & Elaboration \\
\hline 1. & Man speaks. We speak when we are \\
awake and we speak in our dreams. \\
2. Language is - language, speech. \\
3. What does it mean to speak? The \\
current view declares that speech is \\
the activation of the organs for \\
sounding and hearing. Speech is the \\
audible expression and \\
communication of human feelings. \\
4. Speaking is expression. \\
5. Speech is regarded as an activity of \\
man. \\
6. Human expression is always a \\
presentation and representation of the \\
real and the unreal.
\end{tabular}

Source: (Heidegger, 2001). ${ }^{29}$

The six Heidegger's views in looking at language power are the other thing that can be correlated with the classroom as the space to build space of dialogue. Su and Peterson by discussing Heidegger's point of view dealing with language power highlight the importance of defining the existential mode of learning as part of the development of lifelong learning. The language of dynamic movement in the classroom is the indicator of how the language in the class takes place. ${ }^{30}$

The first view "Man speaks. We speak when we are awake and we speak in our dreams" is the sentence that should

\footnotetext{
${ }^{29}$ Heidegger, Poetry, Language, Thought.

${ }^{30}$ Ya hui Su, "Lifelong Learning as Being: The Heideggerian Perspective," Adult Education Quarterly 61, no. 1 (2011): 57-72, https://doi.org/10.1177/0741713610380442;

Thomas E. Peterson, "Notes on Heidegger's Authoritarian Pedagogy," Educational Philosophy and Theory 37, no. 4 (2005): 599-623, https://doi.org/10.1111/j.1469-5812.2005.00143.x.
} 
be understood that speaking is the existence in which men exist. It is supported by Farquhar and Fitzsimons that the power of language emerges in the close association between power and knowledge, in which the ability to define what is real generates the realm of future possibilities. ${ }^{31}$ The most important note to highlight is that a conception of selfhood and subjectivity in terms of freedom, responsibility, and ongoing transformation is needed to create the subjects in the class who are independent of each other. The ability to communicate critically happens. ${ }^{32}$

The space to build space of dialogue is that everyone who speaks should have the goal and target what to speak and to whom to speak; awareness of wholes is suggested as a crucial means for discovering new meanings about ourselves, and Heidegger's perception of art is examined as a source for developing this attentiveness. ${ }^{33}$ Lotz views Heidegger having the concept "'Everyone who actually will know: to actually will is to will nothing else but the ought of one's existence" can be linked to this. ${ }^{34}$

\footnotetext{
31 Sandy Farquhar and Peter Fitzsimons, "Lost in Translation: The Power of Language," Educational Philosophy and Theory 43, no. 6 (2011): 652-62, https://doi.org/10.1111/j.1469-5812.2009.00608.x.

${ }^{32}$ Farquhar and Fitzsimons; D'Agnese, "'Not-Beingat-Home': Subject, Freedom and Transcending in Heideggerian Educational Philosophy."

33 Doron Yosef-Hassidim, "Awareness of Wholes: The Ontological Difference as an Educative Source," Educational Philosophy and Theory 48, $\begin{array}{llll}\text { no. } & \text { (2016): } & \text { 785-97, }\end{array}$ https://doi.org/10.1080/00131857.2016.1165013.

34 Christian Lotz, "Action: Phenomenology of Wishing and Willing in Husserl and Heidegger," Husserl Studies 22, no. 2 (2006): 121-35, https://doi.org/10.1007/s10743-006-9006-7.
}

However, it is important to say that human language could be the aim of humanism when the language used in the classroom happens. ${ }^{35}$

Because of that, speaking signals whether he or she exists and gives meaning to the place in which he or she is. Speaking according to Heidegger's view is that language with the soul that livens spirit to live. Speaking through language is the one that affirms the importance of instilling the values of dreaming. When it is correlated with language power in the classroom, it can be explained through the importance of developing language for creating speaking ability.

Speaking ability in language power is viewed that anybody involved in the classroom should be able to speak meaningfully. Meaningful speaking is the utterances that sound meaningful and contributes towards the goal of speaking. People speak because they have the reason and the reason comes because of logic. Therefore, the language that happens in the classroom in which the teacher and students interact is built on logic and reason. ${ }^{36}$

What should be stated clearly is that language, logic, and speaking ability are the three aspects that should be highlighted for creating the classroom interaction aiming for empowering when it is related to language power in the

\footnotetext{
${ }^{35}$ René V. Arcilla, "Sand Face: Humanism after Antihumanism," Educational Theory 65, no. 6 (2015): 655-64, https://doi.org/10.1111/edth.12140. ${ }^{36}$ A. Fay St, "Heidegger on Logic and Language: Some Aporiai" 3, no. 3 (2014): 421-42.
} 
classroom. The language used to build awareness in speaking, communicating, and interacting. Language-based on Heidegger's view means to drive all subjects in the classroom to be able to attend as active and participative subjects. Language is the soul for all subjects in the classroom to be able to participate in interaction and discussion. It does not only talk about how someone is fluent in speaking, but also how someone has selfawareness in speaking. Speculative thinking in language can be the media for transferring the message. ${ }^{37}$

The next view "language islanguage, speech" also should be interpreted that anybody exists and attends in a situation as the effort that language spoken and uttered is speech itself that gives meaning. Therefore, language is called speech when the communicator and communicant in a situation can position themselves as the subjects who understand their position.

When this concept is connected to language power in the classroom, it is very clear that a teacher and students should be able to put the target of class achievement in which the teacher's attendance goal in the classroom is for delivering the lecture, explaining the topic, discussing it, elaborating the topic, and trying to build comprehensive explanation dealing with the topic of lecture; students in other sides try to pay attention what the teacher delivers and also ask any

\footnotetext{
${ }^{37}$ Carl Mika, "Some Thinking from, and Away from, Heidegger," Educational Philosophy and Theory 48, no. 8 (2016): 827-31, https://doi.org/10.1080/00131857.2016.1165016.
}

questions when they do not understand or have any problems in understanding the topic. That is why, "language is-language, speech" is the linguistic expression to state that there is dialogue among the teacher and students. The language used and uttered is the manifestation that the teacher and students attend for participation to achieve the goal for learning.

The third view "What does it mean to speak?" The current view declares that speech is the activation of the organs for sounding and hearing. Speech is the audible expression and communication of human feelings" enriches the additional view that speech represented through language should reflect the ideas and their thought. Language narrating the ideas and thought should be communicative and simple. Hence, this condition creates a positive atmosphere.

Making interaction is the way to build a positive perception in reaching the goal. Gupta affirms that the interaction that is constructed through communal dialogue has a positive aura in speaking which is called the audible expression and communication of human feelings. ${ }^{38}$ When this concept is applied in the classroom, language should be able to bridge audible expression and communication of human feelings among the teacher and students.

The fourth view "speaking is an expression" deepens a view that linguistic

\footnotetext{
38 Rajeev Kumar Gupta, "An Investigation into Heidegger's Views on Language and Technology w.r.t. 'Enframing,'” Journal of Arts, Culture, Philosophy, Religion, Language and Literature 1, no. 2 (2017): 65-69.
} 
competence the people have in expressing the ideas and thought should be able to mean to drive the pattern of thinking to think and speak openly. Heidegger signals that expressing ideas and thoughts is the goal of speaking expression itself. When this is adapted into classroom language in which the language has a role in the interaction among the teacher and students, it is important to say that the teacher and students should be able to express their ideas and thought in a simple way to create an understandable understanding .

The next view "speech is regarded as an activity of man" is the other perspective in looking at speech as the linguistic activity in which people speak because of gender. Man is supposed privileges in speaking than woman although this view does not represent the trending situation in which man and woman have the same right in speaking. Whatever it is, speech for man and woman is the modality in expressing their identities. When this is correlated with the classroom language, the teacher and students whether male or female should position themselves for expressing identity.

The last view "human expression is always a presentation and representation of the real and the unreal" is the other thing interesting to discuss in looking at language power in the classroom. The teacher in delivering the topic and material can explain anything relevant to students' daily activity or the teacher can take the topic and example unfamiliar to students' daily activity aiming to build students' critical thinking. In other words, they do not only know what they have known but also try to be familiar with what they do not know previously.

To make the students interested and familiar, the teacher's role in using language interesting for students is important to have. Language is a tool of communication. Not all people are interested to speak, except for them who like to speak. In Heidegger's view, embracing all students to be active and participate in the classroom should be able to involve the language use interesting.

\section{Conclusion}

Nietzsche and Heidegger have similarities in treating language in communication. Both of them position language as an expression of consciousness, a reflection of language product constructed grammatically, audible expression and communication of human feelings, and presentation and representation of the real and the unreal. The classroom used as the space of language activity needs to consider Nietzsche's and Heidegger's views in which the language used can contribute towards the goal of learning and students are interested in using their linguistic competence.

\section{References}

Aloni, Nimrod. "Empowering Dialogues in Humanistic Education." Educational Philosophy and Theory, 2011, 1-15. https://doi.org/10.1111/j.14695812.2011.00789.x. 
Arcilla, René V. "Sand Face: Humanism after Antihumanism." Educational Theory 65, no. 6 (2015): 655-64. https://doi.org/10.1111/edth.12140.

Ayling, Douglas. "Language Can Be Thought of as Metaphor. Is This an Appropriate Metaphor?," 2002.

Behler, Ernst, Mazzino Montinari Wolfgang, Heinz Wenzel Band, and New York. The Beginnings of Nietzsche's Theory of Language. New York. Berlin: de Gruyter, 1988.

Bingham, Charles. "The Goals of Language, The Language of Goals: Nietzsche's Concern with Rethoric and Its Educational Implications." Educational Theory 48, no. 2 (1998): 229-40.

Constâncio, João, and Maria João Mayer Branco. Nietzsche on Instinct and Language. Berlin: Walter de Gruyter, 2011.

D'Agnese, Vasco. “'Not-Being-at-Home': Subject, Freedom and Transcending in Heideggerian Educational Philosophy." Studies in Philosophy and Education 37, no. 3 (2018): 287-300.

https://doi.org/10.1007/s11217-0189598-3.

Emden, Christian J. Nietzsche on Language, Consciousness, and the Body. Illinois: University of Illinois Press, 2005.

Farquhar, Sandy, and Peter Fitzsimons. "Lost in Translation: The Power of Language." Educational Philosophy and Theory 43, no. 6 (2011): 65262. https://doi.org/10.1111/j.14695812.2009.00608.x.

Gordon, P. "Language and Consciousness." In Encyclopedia of Consciousness, 2009. https://doi.org/10.1016/B978012373873-8.00043-8.

Grozev, Stanul. "Friedrich Nietzsche on the Origins of Language and Truth." Psychological Research 20, no. 1 (2017): 7-13.
Gupta, Rajeev Kumar. "An Investigation into Heidegger's Views on Language and Technology w.r.t. 'Enframing."' Journal of Arts, Culture, Philosophy, Religion, Language and Literature 1, no. 2 (2017): 65-69.

Harliani, Susi. "The World of Translation." OKARA: Jurnal Bahasa dan Sastra 13, no. 1 (2019): 121. https://doi.org/10.19105/ojbs.v13i1.2 272.

Hazelton, Roger. "Nietzsche's Contribution to the Theory of Language." The Philosophical Review 52, no. 1 (1943): 47-60.

Heidegger, Martin. Logic as the Question Cencerning the Essence of Language. New York: State University of New York Press, 2009. Poetry, Language, Thought. New York: HarperCollins Publishers, 2001. https://doi.org/10.2307/40126613.

James, Carl. "A Cross-Linguistic Approach to Language Awareness." Language Awareness 5, no. 3-4 (1996):

138-48. https://doi.org/10.1080/09658416.19 96.9959903.

Katsafanas, Paul. "Nietzsche's Theory of Mind: Consciousness and Conceptualization." European Journal of Philosophy 13, no. 1 (2005): 1-31. https://doi.org/10.1111/j.09668373.2005.00220.x.

Lichtenberg, Joseph. "Values, Consciousness, and Language." Psychoanalytic Inquiry 22, no. 5 (2002): 841-56. https://doi.org/10.1080/0735169220 9349020.

Lotz, Christian. "Action: Phenomenology of Wishing and Willing in Husserl and Heidegger." Husserl Studies 22, no. 2 (2006): 121-35. https://doi.org/10.1007/s10743-0069006-7. 
Mika, Carl. "Some Thinking from, and Away from, Heidegger." Educational Philosophy and Theory 48, no. 8 (2016): 827-31. https://doi.org/10.1080/00131857.20 16.1165016. $\begin{gathered}\text { Peterson, Thomas E. "Notes on } \\ \text { Heidegger's }\end{gathered}$
Authoritarian Pedagogy." Educational Philosophy and Theory 37, no. 4 (2005): 599623. https://doi.org/10.1111/j.14695812.2005.00143.x.

Rosenthal, David M. "Consciousness and Its Function." Neuropsychologia 46, no. 3 (2008): 829-40. https://doi.org/10.1016/j.neuropsych ologia.2007.11.012.

Schalow, Frank. "Language and the Social Roots of Conscience: Heidegger's Less Traveled Path." Human Studies 21, no. 2 (1998): 141-56.

https://doi.org/10.1023/A:100531210 5548.

Seigel, Jerrold. "The Human Subject as A Language-Effect." History of European Ideas 18, no. 4 (1994): 481-95.

https://doi.org/10.1016/01916599(94)90081-7.

St, A. Fay. "Heidegger on Logic and Language: Some Aporiai" 3, no. 3 (2014): 421-42.

Strong, Tracy B. "Language and Nihilism: Nietzsche's Critique of Epistemology." Theory and Society 3, no. 2 (1976): 239-63. https://www.jstor.org/stable/656848.

$\mathrm{Su}$, Ya hui. "Lifelong Learning as Being: The Heideggerian Perspective." Adult Education Quarterly 61, no. 1 (2011):

57-72. https://doi.org/10.1177/0741713610 380442.

Wales, M. L. "Aspects of Language Awareness Used in Some Workplace Esl Programmes." Language Awareness 2, no. 2 (1993): https://doi.org/10.1080/09658416.19 93.9959823.

Walsh, Steve. "Developing Interactional Awareness in the Second Language Classroom Through Teacher SelfEvaluation." Language Awareness 12, no. 2 (2003): 124-42. https://doi.org/10.1080/0965841030 8667071.

Watson, James R. "Nietzsche's 'Transnational' Thinking." History of European Ideas 15, no. 1-3 (1992): 133-40.

Yacek, Douglas W. "Learning to See with Different Eyes: A Nietzschean Challenge to Multicultural Dialogue." Educational Theory 64, no. 2 (2014):

99-121. https://doi.org/10.1111/edth.12052.

Yosef-Hassidim, Doron. "Awareness of Wholes: The Ontological Difference as an Educative Source." Educational Philosophy and Theory 48, no. 8 (2016): 785-97. https://doi.org/10.1080/00131857.20 16.1165013.

Yu, Jie. "The Pedagogy of Heideggerian (Un)Truth: How Can We See Stars by Day in a Deep Dark Well?" Journal of Curriculum and Pedagogy 11, no. 1 (2014): 50-63. https://doi.org/10.1080/15505170.20 14.893215. 
